\title{
A PEDAGOGIA HISTÓRICO-CRÍTICA E O MARXISMO: Equívocos de (mais) uma crítica à obra de Dermeval Saviani
}

\author{
Newton Duarte ${ }^{1}$ \\ Benedito J. Pinheiro Ferreira $^{2}$ \\ Julia Malanchen ${ }^{3}$ \\ Herrmann V. de Oliveira Muller ${ }^{4}$
}

\begin{abstract}
Se não nos dermos perfeitamente conta de que só se pode criar essa cultura proletária conhecendo com exatidão a cultura criada pela Humanidade em todo o seu desenvolvimento e transformando-a, se não atendermos a isto, nunca poderemos resolver semelhante problema. A cultura proletária não surge de fonte desconhecida, não brota do cérebro dos que se intitulam especialistas na matéria. Seria absurdo pensar assim. A cultura proletária tem de ser o desenvolvimento do conjunto de conhecimentos conquistados pela Humanidade sob o jugo da sociedade capitalista, da sociedade dos latifundiários e burocratas (Lênin, 1977, p. 125).
\end{abstract}

RESUMO:

Este artigo analisa uma tese de doutorado que foi escrita por Ademir Lazarini com o propósito de formular uma crítica radical à interpretação de Dermeval Saviani acerca das relações entre capital e educação. A tese argumenta que a pedagogia histórico-crítica baseada nas obras de Dermeval Saviani distancia-se da teoria marxiana sobre a sociedade capitalista. $\mathrm{O}$ artigo detecta equívocos fundamentais no interior da crítica formulada pelo autor da tese e o exame desses equívocos revelou uma ausência de compreensão do método materialista histórico-dialético.

Palavras-chave: Marxismo, Educação, Pedagogia Histórico-Crítica.

\section{THE HISTORICAL-CRITICAL PEDAGOGY AND THE MARXISM: The mistakes of one (more) criticism to the Dermeval Saviani's works.}

\begin{abstract}
:
This paper analyses a $\mathrm{PhD}$ dissertation which was written by Ademir Lazarini with the purpose to present a radical criticism to the Dermeval Saviani's interpretation of the relation between the capital and the school education. The dissertation argues that the Historical-Critical Pedagogy based on Saviani's works is very distant from the Marxian theory of capitalist society. The paper detects fundamental mistakes inside the criticism formulated by the author of the dissertation and the examination of those mistakes revealed a lack of comprehension of the materialistic historical dialectical method.
\end{abstract}

Keywords: Marxism; Education; Historical-Critical Pedagogy 


\section{Uma denúncia bombástica: Dermeval Saviani apropria-se equivocadamente das categorias de Marx e a pedagogia histórico-crítica não é socialista.}

O tema deste artigo não é novo. Poderíamos resumi-lo a duas perguntas: 1. O marxismo pode fundamentar uma pedagogia que oriente a elaboração e a realização de propostas pedagógicas guiadas pela perspectiva de superação do capitalismo, ou seja, pela perspectiva socialista? 2. A estratégia socialista em direção à superação do capitalismo requereria a luta, no interior do sistema escolar, pela socialização do conhecimento científico, artístico e filosófico em suas formas mais desenvolvidas?

Essas perguntas não são novas e muitos educadores brasileiros têm se empenhado há décadas em responder afirmativamente a ambas. Como representante destacado dos educadores que trabalham arduamente pela construção de uma pedagogia comprometida com a classe trabalhadora, Dermeval Saviani foi homenageado por ocasião do III Encontro Brasileiro de Educação e Marxismo, realizado na Universidade Federal da Bahia em novembro de 2007. Mas não seria a luta travada por Saviani e pelos demais educadores que trabalham na construção da pedagogia histórico-crítica um ato heróico, porém fadado a contribuir, involuntariamente, para a manutenção da sociedade capitalista? Não seriam aplicáveis a esse caso as palavras de Althusser abaixo reproduzidas?

(...) esta é uma das formas essenciais da ideologia burguesa dominante: uma ideologia que representa a escola como um meio neutro, desprovido de ideologia (posto que é laico), em que professores respeitosos da "consciência" e da "liberdade" das crianças que lhes são confiadas (com toda confiança) por seus "pais" (que também são livres, isto é, proprietários de seus filhos), os encaminham para a liberdade, a moralidade e a responsabilidade de adultos mediante seu próprio exemplo, os conhecimentos, a literatura e suas virtudes "liberadoras". Peço perdão por isso aos professores que, em condições espantosas, tentam voltar-se contra a ideologia, contra o sistema e contra as práticas de que são prisioneiros, as poucas armas que possam encontrar na história e no saber que eles "ensinam". São uma espécie de heróis. (ALTHUSSER, 1969 , p. 20).

Essa seria a conclusão a qual deveríamos chegar se concordássemos com a análise da obra de Dermeval Saviani apresentada numa tese de doutorado em educação defendida ao final do ano passado (LAZARINI, 2010). O autor não deixa dúvidas quanto à sua pretensão de demonstrar a incompatibilidade entre a obra de Dermeval Saviani e a luta pelo socialismo:

(...) procurarei demonstrar neste estudo é que Saviani comete erros decisivos em relação a sua principal referência teórica, e esses erros comprometem pela raiz as suas principais teses acerca da relação entre capital e educação formal. Como decorrência desses equívocos, suas principais proposições educacionais, em regra, apresentam incongruências e, no limite, entram em contradição com o projeto histórico socialista que o autor pretende defender (LAZARINI, 2010, p. $35)$.

Por qual motivo o autor se propõe a mostrar que a obra de Saviani, e a pedagogia histórico-crítica no seu conjunto, apresentam equívocos fundamentais? A resposta é que ele considera necessário combater a pedagogia histórico-crítica em nome do marxismo e do socialismo, já que os equívocos dessa pedagogia teriam graves conseqüências: 


\begin{abstract}
No caso de Saviani, que tem na tese do "trabalho como princípio educativo" um dos elementos constitutivos principais da sua Pedagogia Histórico-Crítica, pelas razões anteriormente aventadas, ocorre um distanciamento teórico e prático progressivo em relação àquele projeto histórico que apenas formalmente continua nos seus horizontes. Ao invés da crítica radical à organização social do trabalho vigente e, por conseguinte, preconizar a necessidade histórica imperiosa de inverter a sua lógica atualmente centrada direta ou indiretamente na valorização do capital, os objetivos estratégicos da referida tese centram-se no ensino dos seus processos de trabalho. O que faz sentido apenas para quem preconiza, conforme apresentei anteriormente, que "saber erudito e científico" é igual a conhecimento revolucionário. A "engenharia lógicoformal" permite esse tipo articulação teórica, mesmo que ela seja estranha à realidade social em curso. Uma das principais consequências desse descaminho teórico é que, independentemente da vontade dos seus formuladores, ele acaba constituindo mais um entrave para o desenvolvimento de atividades educacionais teórico-práticas de caráter realmente revolucionário, tanto no limitado e, em regra, hostil campo da educação institucional quanto da educação em geral (LAZARINI, 2010, p. 450-451).
\end{abstract}

Não há dúvida quanto à posição do autor no sentido de que a pedagogia históricocrítica estaria muito longe de se constituir em uma perspectiva educacional marxista. Isso fica evidente na passagem acima quando Lazarini afirma que Saviani, ao invés de se posicionar criticamente em relação à lógica do capital defenderia uma educação escolar centrada no ensino dos processos de trabalho, ou seja, a pedagogia histórico-crítica defenderia a domesticação dos indivíduos ao trabalho alienado. Essa visão acrítica da escola faria sentido aos ingênuos defensores dessa pedagogia porque, entre outros equívocos eles acreditariam que "saber erudito ou científico é igual a conhecimento revolucionário". Diante de equívocos tão fundamentais não seria de se estranhar que Saviani e toda a pedagogia histórico-crítica estivessem, como afirma Lazarini, distantes do projeto socialista, mantendo com este um compromisso meramente formal. Para completar o quadro, os pressupostos dessa pedagogia não teriam fundamento na realidade social em curso e o pensamento de Saviani e seguidores constituir-se-ia num obstáculo para o desenvolvimento de atividades revolucionárias; seja no campo da educação escolar (adjetivado por Lazarini como restrito e hostil), seja no campo da educação em geral (que não recebe nenhuma adjetivação). Diga-se, a propósito das adjetivações empregadas por Lazarini, que ele prefere a expressão "educação formal" a "educação escolar". No mesmo sentido usa a expressão "educadores formais" para referir-se aos professores (LAZARINI, 2010, p. 414).

Esclarecido qual é o alvo da crítica e quais as razões da mesma, cabe perguntar pelo que seja, no entendimento de Lazarini, uma perspectiva revolucionária em educação. Para isso ele chama em seu apoio Istvan Mészáros e Ivo Tonet (LAZARIINI, 2010, p. 410-420). $\mathrm{O}$ autor esforça-se por negar qualquer intenção imobilista seja de suas análises seja daquelas nas quais ele se apóia. Contrapõe Saviani a Mészáros afirmando que a posição do segundo é "muito mais realista e consequente como proposição socialista" (idem, p. 414).

O que Lazarini vê de realista na concepção de Mészáros sobre a educação pode ser resumido a dois pontos: a tese da impossibilidade da educação escolar contribuir, pela socialização do conhecimento, para a luta pelo socialismo e a tese da possibilidade dos "educadores formais" contribuírem para a luta pelo socialismo por meio de ações pontuais 
de mobilização revolucionária. Ou seja, não será transmitindo conhecimento, não será atuando como professores que os "educadores formais" poderão contribuir para a revolução. Não será pela especificidade do trabalho educativo que os professores contribuirão para a revolução. Sim, está claro que não se trata de imobilismo, mas também está claro que não se trata de valorização do trabalho do professor. Não é por acaso que Lazarini, na esteira de outros autores, nega-se a discutir a especificidade da educação escolar, rejeita a tese da pedagogia histórico-crítica acerca da necessidade de socialização do saber sistematizado, e rejeita a afirmação de que a educação escolar seja a forma historicamente mais desenvolvida de educação. Sua visão sobre o que seria uma perspectiva verdadeiramente socialista no campo "restrito e hostil" da educação escolar é sintetizada na seguinte passagem de Tonet:

Daí a impossibilidade de estruturar a educação em seu conjunto, de modo a estar voltada para a emancipação humana. É por isso que entendemos não ser possível uma "educação emancipadora", mas apenas a realização de "atividades educativas emancipadoras". A nosso ver é perda de tempo querer pensar uma educação emancipadora (conteúdos, métodos, técnicas, currículos, programas, formas de avaliação etc.) como um conjunto sistematizado que possa se transformar em uma política educacional (TONET, 2007, p. 35, grifo nosso).

Mészáros compartilharia dessa visão negativa em relação à educação escolar? Vejamos o que ele próprio escreveu:

Nunca é demais salientar a importância estratégica da concepção mais ampla de educação, expressa na frase: "a aprendizagem é a nossa própria vida". Pois muito do nosso processo contínuo de aprendizagem se situa, felizmente, fora das instituições formais. Felizmente porque esses processos não podem ser manipulados e controlados de imediato pela estrutura educacional formal legalmente salvaguardada e sancionada. (...) O pesadelo de 1984, de Orwell, não é realizável precisamente porque a esmagadora maioria das nossas experiências constitutivas permanece - e permanecerá sempre - fora do âmbito do controle e da coerção institucionais formais (MÉSZÁROS, 2005, p. 53-54).

É curioso - e decepcionante - como um intelectual internacionalmente reconhecido por seus estudos no campo da dialética marxista mostra-se tão pouco dialético ao analisar tanto a educação escolar como a educação "ao longo de toda a vida". A educação fora da escola parece ser imune à internalização da ideologia dominante e da lógica do capital. Mais do que isso, ela seria a verdadeira fonte de forças e recursos para resistir a essa internalização dentro do próprio sistema escolar:

O fato da educação formal não poder ter êxito na criação de uma conformidade universal não altera o fato de, no seu todo, ela estar orientada pra aquele fim. Os professores e alunos que se rebelam contra tal desígnio fazem-no com a munição que adquiriram tanto dos seus companheiros rebeldes, dentro do domínio formal, quanto a partir da área mais ampla da experiência educacional "desde a juventude até a velhice" (Mészáros, 2005, p. 55-56). 
Mészáros dá um exemplo de sua própria vida, o fato dele ter encontrado aos oito anos de idade, fora do sistema "formal" de educação, um escritor que muito o influenciou. Entretanto caberia a pergunta: essa influência teria sido possível sem o conhecimento adquirido na escola?

Lazarini considera a perspectiva de Mészáros sobre a educação na sociedade capitalista mais realista que a de Saviani e afirma que a defesa, pela pedagogia históricocrítica, da socialização do saber sistematizado apoiar-se-ia numa equivocada identificação entre saber científico e saber revolucionário. Será que Lazarini, ao citar várias vezes o marxista húngaro Georg Lukács, esqueceu-se que este valorizava o conhecimento acumulado pela humanidade e, por exemplo, no campo das artes considerava indispensável o conhecimento, pelos indivíduos, das obras dos grandes clássicos? Será que Lazarini pensa que Marx e Engels, ao saudarem com entusiasmo a teoria da evolução de Darwin, teriam incorrido no mesmo tipo de visão ingênua da ciência que ele acredita existir em Saviani? Será que Gramsci também estava distante da perspectiva socialista ao analisar o significado historicamente positivo que teve o ensino de grego e de latim na escola tradicional? Perguntamos também se Lênin estaria, tal como Saviani, distante do socialismo ao fazer as seguintes afirmações, em outubro de 1920, portanto três anos após a revolução russa, num discurso proferido no II Congresso da União das Juventudes Comunistas:

\footnotetext{
Para chegarmos a ser comunistas, temos que enriquecer inevitavelmente a memória com os conhecimentos de todas as riquezas acumuladas pela humanidade. Não queremos um ensino mecânico, mas necessitamos de desenvolver e aperfeiçoar a memória de cada estudante, proporcionandolhe fatos essenciais, porque o comunismo seria um vácuo, ficaria reduzido a uma fachada incaracterística, o comunista não passaria de um fanfarrão, se não compreendesse e assimilasse todos os conhecimentos adquiridos. Não só os deveis assimilar, mas fazer de forma crítica, para não amontoar qualquer parágrafo inútil no cérebro, mas enriquecer ele com o conhecimento de todos os fatos, sem os quais não se torna possível ser um homem culto na época em que vivemos (Lênin, 1977, p. 126).
}

Os autores deste artigo situam-se no campo socialista, estudam Marx, Engels, Lênin, Gramsci, Lukács, Vigotski, Leontiev e outros autores do universo marxista e propõem-se a contribuir, dentro de seus limites, para a construção da pedagogia históricocrítica, somando esforços à luta travada no campo da educação brasileira por Dermeval Saviani. Entendemos que uma perspectiva revolucionária socialista não prescinde do domínio, como frisou Lênin, das formas mais avançadas do conhecimento construído na história da humanidade, incluindo-se o conhecimento construído no capitalismo.

Mas para reafirmarmos essa perspectiva defendida pela pedagogia histórico-crítica em oposição às principais teses defendidas por Lazarini, precisamos inicialmente abordar a crítica que ele faz à concepção do trabalho educativo como uma produção não material.

\section{Os fundamentos da crítica: um materialismo grosseiro e uma concepção não dialética do capitalismo.}

Nos momentos de sua tese de doutorado nos quais Lazarini parece acreditar que suas críticas a Saviani são as mais contundentes e demolidoras é que se revelam a quem queira ver as inconsistências de seus pressupostos. É o caso, por exemplo, do item "A educação como trabalho não material: simbiose entre idealismo e empirismo sensitivo" 
(LAZARINI, 2010, p. 429-441) no qual, seja assinalado, o autor pouco faz além de repetir quase ao pé da letra a crítica já feita por Lessa (2007, p. 105-125) à concepção de educação como trabalho não material segundo Dermeval Saviani. Nesse item mostra-se claramente uma concepção que confunde materialidade com objetividade.

O mencionado item começa apresentando as considerações de Saviani sobre o trabalho educativo no texto "Sobre a natureza e a especificidade da educação", integrante do livro Pedagogia Histórico-Crítica. Nesse texto, como é sabido, Saviani procura analisar a especificidade da educação escolar e para isso toma por base a distinção feita por Marx (1974, 346-347) entre dois tipos de produção não material (ou imaterial):

\begin{abstract}
A produção não material, ainda que seja levada a cabo tão somente para a troca, isto é, quando produz mercadorias, pode ser de dois tipos: 1. Resulta em mercadorias, valores de uso que tem uma forma distinta dos produtores e consumidores e independente destes; essas mercadorias podem existir, pois, durante um intervalo entre a produção e o consumo e nesse intervalo circular como mercadorias vendáveis, tais como os livros, quadros, em uma palavra, todos os produtos artísticos distintos da execução artística ou do artista que os executa. (...) 2. A produção não pode separar-se do ato de produzir, como ocorre com todos os artistas, oradores, atores, professores, médicos, sacerdotes etc.
\end{abstract}

Lazarini, entretanto, apresenta essa distinção como se ela tivesse sido inventada por Saviani como uma alternativa às categorias marxianas, de trabalho produtivo e trabalho improdutivo, como, aliás, sugere o título do item 1.1 da tese de Lazarini, a saber: "A educação como trabalho não-material: alternativa explicativa de Saviani às categorias trabalho produtivo e trabalho improdutivo" (LAZARINI, 2010, p. 56). Depois voltaremos à posição de Saviani acerca da necessidade das categorias de produção material e produção não material para a compreensão da especificidade do trabalho educativo. Por ora queremos analisar as razões pelas quais Lazarini, contrariamente a Marx, se recusa a aceitar a existência de uma produção não material. Vejamos como se expressa o autor da tese:

Neste ponto, os termos de Saviani entram em contradição irreconciliável
com a sua referência teórica matricial: o materialismo marxiano. Isso se
dá tanto naquilo que concerne à compreensão dos fundamentos teórico-
filosóficos quanto nos fundamentos econômicos desse matiz [sic] teórico.
Neste momento, enfocarei apenas o primeiro aspecto da problemática.
Para tanto, começo recuperando uma premissa do materialismo histórico
fundado por Marx e Engels, trazida à tona por Lessa: "Tudo o que existe
é matéria, o 'não-material' é rigorosamente inexistente" (LAZARINI,
2010, p. 430-431).

Para aceitarmos a afirmação de que tudo o que existe é matéria, teríamos que identificar objetividade com materialidade. Nesse caso, o que não fosse material não teria existência. Por essa razão não pode existir, para Lessa e para Lazarini, a produção não material pois seria uma produção que resultaria num produto inexistente, ou seja, resultaria em nada. O equívoco, porém, não está em Saviani, mas sim na identificação feita por Lessa e adotada por Lazarini, entre o que é material e o que é objetivo.

As diferenças entre os conceitos de materialidade e idealidade na perspectiva marxista foram trabalhadas pelo filósofo soviético Evald V. Ilyenkov, num texto intitulado "O Conceito de Ideal" (ILYENKOV, 1977). Dados os limites de espaço apresentaremos 
essa distinção de maneira bastante breve, a partir do estudo desse texto realizado por Duarte (2003, p. 85-102). Em termos dialéticos o pólo oposto ao da materialidade é o da idealidade. Já a objetividade tem como pólo oposto a subjetividade. Os produtos da atividade humana possuem objetividade social, sejam eles produtos materiais ou ideais. A linguagem é um produto da atividade humana e possui objetividade social, mas ela não é um produto material. A compreensão do caráter objetivo dos produtos das atividades humanas, sejam eles materiais ou não, exige a compreensão do conceito marxiano de objetivação, que foi trabalhado por Duarte (1993 e 2000). Na esteira da identificação feita por Lessa entre materialidade e objetividade, Lazarini, ao que parece, entende que a objetivação realizada no trabalho significaria que o trabalho sempre gera um produto e um trabalho não material seria um trabalho sem produto:

O resultado dessa imbricação física e intelectual que pressupõe o trabalho humano é a objetivação de alguma coisa. Foi neste sentido que Lessa criticou o idealismo contido nas formulações pertinentes ao "trabalho não-material" de Saviani (LAZARINI, 2010, p. 432).

Mas o fato do trabalho ser uma atividade objetivadora não significa, de forma alguma, na teoria de Marx, que a objetivação sempre resulte em produtos materiais. Por exemplo, ao analisar, na sociedade capitalista, o caráter produtivo ou improdutivo do trabalho, dá o seguinte exemplo:

Se for permitido escolher um exemplo fora da esfera da produção material, então um mestre-escola é um trabalhador produtivo se ele não apenas trabalha as cabeças das crianças, mas extenua a si mesmo para enriquecer o empresário. $\mathrm{O}$ fato de que este último tenha investido seu capital numa fábrica de ensinar, em vez de numa fábrica de salsichas, não altera nada na relação (MARX, 1996b, p. 138).

A fábrica de salsichas situa-se na esfera da produção material. Marx dá um exemplo fora da esfera da produção material e escolhe o da fábrica de ensinar, cujo trabalhador é o professor. O trabalho do professor, em determinadas condições pode gerar mais valia, ou seja, pode ser produtivo segundo a lógica capitalista. Mas ele situa-se fora da esfera da produção material. Perguntamos: o que está fora da esfera da produção material não estaria na esfera da produção imaterial?

Quando diferencia o valor de uso da mercadoria de seu valor para a economia capitalista, Marx explica que:

Em direta oposição à palpável e rude objetividade dos corpos das mercadorias, não se encerra nenhum átomo de matéria natural na objetividade de seu valor. Podemos virar e revirar uma mercadoria, como queiramos, como coisa de valor ela permanece imperceptível. Recordemo-nos, entretanto, que as mercadorias apenas possuem objetividade de valor na medida em que elas sejam expressões da mesma unidade social de trabalho humano, pois sua objetividade de valor é puramente social e, então, é evidente que ela pode aparecer apenas numa relação social de mercadoria para mercadoria. (MARX, 1996a, p. 176, grifo nosso).

O valor da mercadoria existe objetivamente, mas não tem nenhum átomo de matéria. Trata-se de uma objetividade social, que é distinta da materialidade. 
Retomando o início do argumento de Lazarini: ele afirmou que Saviani estaria em oposição ao materialismo histórico por definir o trabalho educativo como produção não material. Apoiando-se na mencionada crítica de Lessa (2007, p. 105-125) a Saviani, Lazarini afirma que Saviani incorreria numa concepção dualista que separa o material do espiritual, dualismo esse que já teria sido exaustivamente criticado por Marx. Tanto Lessa quanto Lazarini caem naquilo que acusam em Saviani, ou seja, são eles que não conseguem entender a dialética entre materialidade e idealidade, bem como entre objetividade e subjetividade. Para ambos o fato de Saviani definir o trabalho educativo como produção não material significaria afirmar que uma aula é menos real, menos objetiva que um martelo:

Uma aula (o exemplo dado por Saviani) é tão real, tão existente, quanto um martelo. As diferenças profundas entre a aula e o martelo (...) não incluem nenhuma diferença no que diz respeito ao quantum de ser, à existência, dos dois entes. Eles são, do ponto de vista ontológico, rigorosamente do mesmo estatuto: um não é mais ser, mais existente, mais real, mais material, que o outro. (LESSA, 2007, p. 110-111).

Lessa consegue fazer um raciocínio tão às avessas que quase chega a esconder o fato de que seu argumento não tem consistência. O fato das idéias não serem matéria não as torna menos reais. Como citamos acima, Marx afirma que o valor não contém nenhum resíduo de matéria, mas nem por isso deixa de ter objetividade social. O pensamento de Saviani não dá qualquer margem para a conclusão de que o tipo de objetivação que ocorre em uma aula gere um produto menos real do que um martelo. Esse argumento é insustentável e parte da identificação feita por Lessa entre o ser, o real e o material. Por não conseguir entender a dialética entre produção material e produção não material, Lessa e Lazarini afirmam que Saviani cai em contradições insolúveis quando analisa a materialidade da ação educativa, ou seja, do trabalho educativo, que Saviani inclui na categoria de Marx de produção não material na qual o produto não se separa do ato de produção. Ora, somente haveria contradição se a produção não material ocorresse num mundo não humano, se Saviani estivesse fazendo teologia ao invés de analisar a especificidade do trabalho dos professores. Assim como a produção material exige o pensamento, a linguagem e os conhecimentos que são, conforme Duarte (1993) objetivações não materiais, a produção não material não existe sem as determinações materiais, a começar da própria materialidade do corpo humano e dos recursos materiais empregados, por exemplo, numa aula.

Lazarini apóia-se, portanto, nessa insustentável concepção de Lessa que, em nome do materialismo de Marx afirma que só existe o que é material, negando a objetividade dos fenômenos não materiais e mostrando-se incapaz de entender no pensamento de Saviani a dialética entre a objetivação humana material e não material. Desse materialismo grosseiro e anti-dialético, Lessa e Lazarini concluem que o pensamento de Saviani seria uma mistura de idealismo (o trabalho educativo como produção não material) com empirismo (a materialidade do ato educativo). Trata-se de um raciocínio aparentemente complexo e rigoroso, mas que na realidade é equivocado e confuso, beirando a falaciloquência e o pedantismo.

No caso da tese de Lazarini, a fragilidade da argumentação crítica é conseqüência do caráter não dialético de sua compreensão do pensamento de Marx. Isso fica evidente quando o autor aborda a questão da dialética na nota de rodapé de número 63 (LAZARINI, 2010, p. 98-99), onde Lazarini explica que emprega a designação "materialismo histórico" ao invés de "materialismo histórico e dialético" porque esta segunda conteria uma 
separação entre o materialismo histórico e o materialismo dialético. Segundo o autor, a expressão materialismo histórico e dialético implicaria "defender a existência de uma dialética da natureza isonômica a dos homens, implica, por decorrência, assumir que a natureza possui intencionalidade e causalidade posta no seu movimento". A expressão materialismo dialético, empregada, por exemplo, entre outros grandes autores marxistas, por Lukács (2004, p. 81), não implica de maneira nenhuma a transposição para a natureza de processos essencialmente sociais como é o caso da teleologia e da causalidade posta. Essa afirmação de Lazarini é totalmente desprovida de sentido. Por outro lado, o reconhecimento das especificidades do ser social perante o ser natural não significa, na perspectiva marxista, que não se reconheça a existência da dialética na natureza. Há categorias dialéticas que são específicas ao ser social, mas há outras que estão presentes tanto no ser social quando na natureza. Além disso, o argumento de Lazarini para empregar apenas a designação "materialismo histórico" é o de que a abordagem dialética estaria já contida na perspectiva materialista histórica. Poderíamos fazer o raciocínio inverso, ou seja, que a abordagem dialética da atividade humana - cuja gênese encontra-se na dialética entre ser humano e natureza por meio da atividade de trabalho - é que possibilita uma correta compreensão da historicidade essencial do gênero humano. Embora Lazarini afirme ter como uma de suas referências a análise que Lukács faz da categoria trabalho na obra Ontologia do Ser Social (LUKÀCS, 2004), acaba revelando uma enorme dificuldade em compreender as relações entre a humanização e a alienação pelo trabalho. Tal dificuldade parece decorrer do não domínio da relação entre dialética e história na concepção de Marx. Essa é a questão de fundo que impede Lazarini de entender o papel revolucionário do capital na história humana e de entender a dialética entre a positividade e a negatividade do trabalho no período histórico marcado pelas relações capitalistas de produção. A visão não dialética dessas questões por Lazarini mostra-se, por exemplo, na seguinte passagem:

O trabalho subordinado aos ditames da acumulação capitalista, ou seja, à ininterrupta produção e valorização do valor não pode gerar outra coisa que não seja mais capitalismo, ou seja, mais subsunção real do trabalho ao capital e, concomitantemente, mais alienação e mais reificação. A ampliação desta subsunção e, por conseguinte, das consequências que lhe são próprias, por sua vez, engendram mais domínio do capital sobre o conjunto da reprodução social que, paulatinamente, tem de se adequar direta ou indiretamente à sua lógica de autovalorização. A positividade das relações capitalistas de produção, tal como insistiu reiteradamente Marx, está em engendrar as condições potenciais da sua própria superação. Isso porque só assim estariam realmente abertas as possibilidades históricas para a edificação de uma forma de organização superior da sociedade onde os "livres produtores associados" (de uma possível sociedade sem classes) possam organizar a produção da riqueza material e espiritual da humanidade sem a mediação prioritária de produzir e reproduzir capital, tal como ocorre com a sociedade capitalista (LAZARINI, 2010, p. 164-165, grifo nosso).

A uma primeira e superficial leitura poderia parecer que essa passagem desautorizaria nossa crítica à dificuldade de Lazarini em compreender o caráter historicamente revolucionário do capitalismo, pois, afinal, ele reconheceria a existência da "positividade das relações capitalistas de produção". Mas a única positividade que ele reconhece é a de elas gerarem as condições de sua superação. Mas na mesma passagem o autor afirmou que o trabalho, sob as condições do capitalismo, só gera mais capital e mais 
alienação. Assim a única positividade da sociedade capitalista seria a de gerar as condições para que um dia seja superada sua total negatividade. Nesse raciocínio não há materialismo, nem dialético nem histórico. Lazarini, repete, talvez sem o saber, um erro que o próprio Lukács admitiu, em 1967, existir em seu livro de 1922, História e Consciência de Classe:

\begin{abstract}
A grande idéia de Marx, segunda a qual até mesmo a "produção pela produção significa tão somente o desenvolvimento das forças produtivas do homem, isto é, o desenvolvimento da riqueza da natureza humana como fim em si”, coloca-se fora daquele domínio que História e Consciência de Classe está em condições de examinar. A exploração capitalista perde esse lado objetivamente revolucionário, e não se compreende o fato de que, "embora esse desenvolvimento das capacidades do gênero homem se efetue, de início, à custa da maioria dos indivíduos e de certas classes, ele acaba por romper com esse antagonismo e coincidir com o desenvolvimento de cada indivíduo". Não se compreende, portanto, que "o desenvolvimento superior da individualidade é conquistado apenas por um processo histórico em que os indivíduos são sacrificados". Desse modo, tanto a exposição das contradições do capitalismo como a da revolução do proletariado adquirem uma ênfase involuntária de subjetivismo dominante (LUKÁCS, 2003, p. 16-17).
\end{abstract}

Tendo mostrado os equívocos do tipo de materialismo adotado por Lazarini em sua crítica a Saviani, bem como a fragilidade dessa crítica no que diz respeito ao domínio do método dialético, passemos agora ao ataque demolidor que Lazarini acredita ter desferido sobre a pedagogia histórico-crítica.

\title{
Laborando no equívoco: porque Lazarini foge da análise do conceito de trabalho educativo e rejeita a importância da socialização do conhecimento sistematizado para o processo de superação da sociedade capitalista.
}

Lazarini repete várias vezes ao longo de toda a tese que um dos grandes equívocos de Saviani seria o de recusar-se a analisar a atividade do professor à luz dos conceitos de trabalho produtivo e trabalho improdutivo. Ainda segundo Lazarini, ao invés de Saviani adotar esses conceitos e fazer uma análise crítica do trabalho na sociedade capitalista, opta por uma via acrítica e idealista, ao tomar o trabalho como modelo para a formação humana e ao definir a atividade educativa como trabalho não material.

Já mostramos acima que o conceito de produção não material não é uma invenção resultante de arroubos idealistas de um educador, sendo, isto sim, um conceito empregado por Marx. Acreditamos que não haja necessidade de insistirmos nesse ponto, mas como Lazarini (2010, p. 172) afirmou que "uma brilhante definição do caráter sócio-histórico cumulativo dos homens, tanto instrumental quanto ideal, foi dada pelo psicólogo marxista Alexis Leontiev" não será ocioso mencionar que Leontiev também emprega as categorias de produção material e não material:

Essa nova forma de acumulação da experiência filogenética pode aparecer no homem, na medida em que a atividade especificamente humana tem um caráter produtivo, contrariamente à atividade animal. Esta atividade produtiva dos homens, fundamental entre todas, a atividade do trabalho. O trabalho, realizando o processo de produção (sob 
as duas formas, material e intelectual) imprime-se no seu produto (Leontiev, 1978, p. 165).

Neste momento, porém, gostaríamos de voltar nossas atenções para os argumentos de Saviani no que se refere à utilização dos conceitos de trabalho produtivo e improdutivo para análise do trabalho do professor. Mas neste caso não recorreremos a citações de passagens que Lazarini desconsidera nas obras dos autores que lê. Reproduziremos uma passagem de Saviani citada por seu "demolidor" crítico, para que o leitor tenha certeza de que o autor da crítica leu essa passagem:

Parece-me, pois, que tentar compreender o significado do trabalho em educação pela polarização entre trabalho produtivo e trabalho improdutivo é laborar no equívoco. Trata-se, aí, de uma polarização inadequada porque nós poderemos ter tanto o trabalho em educação que gera mais-valia como um trabalho em educação que não gera mais-valia. $\mathrm{Na}$ verdade o chamado setor de serviços tem esse nome porque se liga à aquisição de bens que têm valor de uso direto. No entanto, os serviços não são, enquanto tais, elementos improdutivos porque eles podem se dar tanto na forma de geração de mais-valia como não. Na medida em que eu compro um determinado serviço por dinheiro, eu não estou com isso extraindo mais-valia. Eu só extraio mais-valia na medida em que eu compro determinado serviço por dinheiro enquanto capital. (...) Portanto, a polarização entre trabalho produtivo e trabalho improdutivo é inadequada para a compreensão da natureza do trabalho em educação. Parece-me que a contraposição correta seria entre trabalho material e trabalho não-material. (Saviani, apud LAZARINI, 2010, p. 57, grifos nossos).

Grifamos uma parte da citação, pois Lazarini não parece ter prestado atenção à mesma. O que Saviani explica é que a categoria de trabalho não-material mostra-se mais adequada à tentativa de compreensão do significado do trabalho em educação, isto é, à caracterização da especificidade da educação escolar perante outras modalidades da prática social. Saviani não está afirmando que as categorias de trabalho produtivo e improdutivo não se apliquem ao trabalho do professor, mas que elas não explicam a especificidade desse trabalho. Elas não explicam, ademais, a especificidade de nenhuma forma de trabalho concreto, pois se referem ao trabalho abstrato, ao processo de valorização e de extração da mais-valia. Isso faz parte do abc do marxismo. Quando Saviani parte da distinção marxiana, no campo da produção não material, entre as atividades nas quais o produto se separa do ato da produção e aquelas nas quais o produto não se separa do ato da produção, seu objetivo não é negar a existência de alienação no trabalho do professor na sociedade capitalista; muito menos negar a existência de alienação em qualquer forma de trabalho nessa sociedade. Seu objetivo é caracterizar a especificidade da atividade educativa escolar, que ele faz com sua já clássica definição:

Portanto, o que não é garantido pela natureza tem que ser produzido historicamente pelos homens, e aí se incluem os próprios homens. Podemos, pois, dizer que a natureza humana não é dada ao homem, mas é por ele produzida sobre a base da natureza biofísica. $\mathrm{O}$ trabalho educativo é o ato de produzir, direta e intencionalmente, em cada indivíduo singular, a humanidade que é produzida histórica e coletivamente pelo conjunto dos homens. Assim, o objeto da educação diz respeito, de um 
lado, à identificação dos elementos culturais que precisam ser assimilados pelos indivíduos da espécie humana para que eles se tornem humanos e, de outro lado e concomitantemente, à descoberta das formas mais adequadas para atingir esse objetivo. (SAVIANI, 2003, p. 13).

Essa definição ontológica de trabalho educativo excluiria a compreensão crítica das formas pelas quais a educação escolar, na sociedade capitalista, reproduziria a alienação? Neste momento do artigo parafrasearemos o próprio Lazarini, quando ele afirma, a respeito de Mészáros: "É preciso ignorar completamente a sua obra ou agir com muita má fé a respeito dela para lhe imputar um caráter imobilista, seja qual for a natureza" (LAZARINI, 2010, p. 414). Afirmamos em relação a Saviani: é preciso ignorar completamente a sua obra ou agir com muita má fé a respeito dela para lhe imputar um caráter de indiferença para com a alienação produzida pelo capital e reproduzida em todos os âmbitos da sociedade capitalista. Não estamos é claro, afirmando que Lazarini ignore completamente a obra de Saviani ou que ele aja com muita má fé em relação à mesma. Mas sua leitura é inegavelmente parcial e distorcida. O que se pode dizer de uma tese de aproximadamente 500 páginas dedicada a uma análise crítica da obra de Saviani que não analisou, nem mesmo citou, o conceito de trabalho educativo? Sim, é isso mesmo o que aconteceu, acredite ou não o leitor! Lazarini limitou-se a criticar o conceito marxiano de produção não-material no qual Saviani se apóia, e a idéia gramsciana do trabalho como princípio educativo, mas não analisou o conceito, este sim, de Saviani, de trabalho educativo.

Aliás, a propósito da concepção gramsciana do trabalho como princípio educativo, citaremos aqui uma passagem do comunista italiano, considerando-se a insistência com que Lazarini afirma ser esse princípio algo tão distante do marxismo:

A escola, mediante o que ensina, luta contra o folclore, contra todas as sedimentações tradicionais de concepções do mundo, a fim de difundir uma concepção mais moderna, cujos elementos primitivos e fundamentais são dados pela aprendizagem da existência de leis naturais como algo objetivo e rebelde, às quais é preciso adaptar-se para dominálas, bem como de leis civis e estatais que são produto de uma atividade humana estabelecidas pelo homem e podem ser por ele modificadas visando a seu desenvolvimento coletivo; a lei civil e estatal organiza os homens do modo historicamente mais adequado à dominação das leis da natureza, isto é, a tornar mais fácil o seu trabalho, que é a forma própria através da qual o homem participa ativamente na vida da natureza, visando transformá-la e socializá-la cada vez mais profunda e extensamente. Pode-se dizer, por isso, que o princípio educativo sobre o qual se baseavam as escolas elementares era o conceito de trabalho (...) $\mathrm{O}$ conceito e o fato do trabalho (da atividade teórico-prática) é o princípio educativo imanente à escola elementar, já que a ordem social e estatal (direitos e deveres) é introduzida e identificada na ordem natural pelo trabalho (GRAMSCI, 1982, p. 130).

Mas não foi somente do conceito de trabalho educativo que Lazarini preferiu se esquivar, mas também da própria utilização dos conceitos de trabalho produtivo e improdutivo na análise da atividade educativa. Ele critica Saviani por não empregar esses conceitos, mas o fato é que ele mesmo não o faz. Quando muito analisa duas passagens onde Marx, ao explicar que um trabalho pode ser improdutivo em certas condições e produtivo em outras, exemplifica com o caso do trabalho do professor. Nesse ponto, talvez Lazarini não tenha percebido, mas não há discordâncias entre ele e Saviani. Ambos 
reconhecem - e seria estranho se não reconhecessem - que o trabalho do professor pode, em certas circunstâncias, gerar mais-valia. Seremos repetitivos: Saviani não afirma que o trabalho do professor não possa ser objeto da exploração capitalista. O que ele afirma é que para sabermos como lutar pelo socialismo no âmbito da educação escolar precisamos conhecer o que caracteriza a especificidade da atividade educativa escolar. Ou seja, ele afirma que precisamos agir exatamente naquele âmbito do qual a pena crítica de Lazarini esquivou-se de forma inaceitável.

Retomando a questão da aplicação das categorias de trabalho produtivo e improdutivo na tese de Lazarini, o fato é que ele não consegue demonstrar de que forma essa aplicação pode contribuir para o trabalho do professor numa perspectiva socialista. Curiosamente, uma questão tão importante para os argumentos defendidos por Lazarini acaba sendo reduzida a uma curta nota de rodapé ("curta" se considerarmos a extensão média das 380 notas de rodapé da tese) nos seguintes termos:

Uma das hipóteses deste estudo é que a decifração do significado social das várias modalidades de atividade docente que ocorrem no interior da sociedade capitalista contemporânea só pode ser radicalmente realizada à luz da compreensão das categorias trabalho produtivo e trabalho improdutivo, tal como foram explicitadas por Marx. (LAZARINI, 2010, p. 109).

Mas tal hipótese não sai da condição dessa modesta nota de rodapé e no restante da tese Lazarini acabou, dessa forma, comprovando não essa sua hipótese, mas a citada afirmação de Saviani, ou seja, "que tentar compreender o significado do trabalho em educação pela polarização entre trabalho produtivo e trabalho improdutivo é laborar no equívoco" (Saviani, apud LAZARINI, 2010, p. 57). O crítico laborou vários anos e produziu uma tese de doutorado de quase quinhentas páginas apoiando-se em um equívoco. Se tivesse compreendido o que Saviani alertara, poderia ter dedicado seus esforços a algo que contribuísse de fato para a luta pelo socialismo.

Como não é raro acontecer, um equívoco levou a outro. A recusa a considerar a especificidade do trabalho educativo levou à incompreensão do papel da socialização do conhecimento no processo de superação do capitalismo.

A categoria dialética de contradição nem sempre é bem compreendida, muito menos bem empregada por pensadores marxistas e não marxistas. Sendo a dialética uma forma superior de pensamento, que supera por incorporação a lógica formal, é compreensível a dificuldade que todos temos em dominar essa forma superior de pensamento. Essa dificuldade acentua-se pelo fato de que não estão universalizadas, em nossa sociedade, nem mesmo as ferramentas lógico-metodológicas necessárias a um raciocínio coerente e bem estruturado. Se há dificuldade em raciocinar-se de forma coerente, mais ainda em raciocinar-se dialeticamente. Essa é uma das razões pelas quais a luta pela socialização do conhecimento sistematizado pela educação escolar se faz tão importante. O principal campo no qual se trava a luta entre aqueles que defendem a socialização do conhecimento e aqueles que são contra essa socialização é o da educação escolar. A classe burguesa e seus intelectuais têm lutado incansavelmente para que a escola não socialize o conhecimento sistematizado.

Marx mostrou que uma das condições do processo de exploração do trabalhador pelo capital é que o trabalhador possua tão somente sua força de trabalho e não disponha dos meios de produção sem os quais essa força de trabalho não pode transformar-se em atividade. Mas a força de trabalho deve se reproduzir e, para tanto, é necessário satisfazer algumas necessidades do trabalhador. Interessa ao capital reduzir ao mínimo os custos da 
reprodução da força de trabalho, ou seja, para isso é preciso reduzir ao mínimo as necessidades do trabalhador. Entre elas encontra-se a necessidade de conhecimento. Além dessa questão dos custos de reprodução da força de trabalho, há a questão do controle dos meios de produção. Claro que o capitalista tem o elemento fundamental para esse controle que é o próprio capital, mas como os meios de produção carregam conhecimento objetivado, é preciso que a classe burguesa lute pelo controle da produção e distribuição do conhecimento. A escola é, nesse aspecto, um problema para a burguesia que precisa manter o controle sobre a quantidade de conhecimento que é difundido pela educação escolar e sobre os tipos de conhecimento que ela difunde.

A escola é marcada por uma contradição. Saviani (2005, p. 223-271) analisa essa contradição entre a função precípua da escola pública - a difusão do saber - e a tendência inerente à sociedade capitalista que é a da propriedade privada dos meios de produção. Nessa perspectiva, afirma o educador marxista:

O desenvolvimento da educação e, especificamente, da escola pública, entra em contradição com as exigências inerentes à sociedade de classes de tipo capitalista. Esta, ao mesmo tempo que exige a universalização da forma escolar de educação, não a pode realizar plenamente, porque isso implicaria a sua própria superação. Com efeito, o acesso de todos, em igualdade de condições, às escolas públicas organizadas com o mesmo padrão de qualidade, viabilizaria a apropriação do saber por parte dos trabalhadores. Mas a sociedade capitalista se funda exatamente na apropriação privada dos meios de produção. Assim o saber, como força produtiva independente do trabalhador, se define como propriedade privada do capitalista. $\mathrm{O}$ trabalhador, não sendo proprietário dos meios de produção, mas apenas de sua força de trabalho não pode, portanto, se apropriar do saber. Assim, a escola pública, concebida como instituição de instrução popular destinada, portanto, a garantir a todos o acesso ao saber, entra em contradição com a sociedade capitalista (SAVIANI, 2005, p. 256-257).

É cansativo para o leitor e para os autores deste artigo ter que saturá-lo com grandes citações de textos já bem conhecidos de Saviani e outros autores marxistas. Mas nos vemos obrigados a isso em razão das distorções que Lazarini faz do pensamento de Saviani. Vejase o exemplo da citação acima. Somente uma imensa vontade de não entender o que está escrito poderia levar alguém a interpretar o raciocínio de Saviani como se ele estivesse afirmando que a escola pública pode alcançar na sociedade capitalista a plena socialização do saber sistematizado e que, quando isso ocorrer, a escola terá produzido a passagem do capitalismo ao socialismo. Pois bem, acredite ou não o leitor, é essa a interpretação que Lazarini tem do pensamento de Saviani. Numa nota de rodapé ele afirma que "Saviani não só defenderá a possibilidade da construção da hegemonia de uma perspectiva socialista nas instituições escolares controladas pelo Estado capitalista, mas também que a universalização de escolas públicas de caráter unitário nos ensinos fundamental e médio levaria mesmo à superação da ordem social vigente" (LAZARINI, 2010, p. 87). O que Saviani afirma, com toda a razão, é que a luta por um sistema público de ensino que realize a função da escola, que é a de socializar o saber sistematizado, entra em contradição com lógica da sociedade capitalista e que, portanto, a luta pela escola pública só faz realmente sentido quando é parte da luta pelo socialismo: 
(...) na sua radicalidade, o desafio posto pela sociedade de classes do tipo capitalista à educação pública só poderá ser enfrentado em sentido próprio, isto é, radicalmente, com a superação dessa forma de sociedade. A luta pela escola pública coincide, portanto, com a luta pelo socialismo (...). Em conclusão, o enfrentamento dos desafios postos à educação pública pela sociedade de classes passa, do ponto de vista da pedagogia histórico-crítica, pela luta por uma escola pública que garanta aos trabalhadores um ensino da melhor qualidade possível nas condições históricas atuais, entendida como um componente na luta mais ampla pela superação da própria sociedade de classes. (SAVIANI, 2005, p. 257 e 271).

Afirmei que na crítica que Lazarini pretendeu fazer a Saviani, um equívoco levou a outro. O crítico esquivou-se de discutir a especificidade do trabalho educativo, laborando no equívoco de que seria suficiente, para compreender-se a educação escolar na sociedade capitalista, empregar as categorias de trabalho produtivo e improdutivo, chegando ao único resultado de mostrar o que Saviani já afirmara, ou seja, que essas categorias não dão conta da especificidade da educação. Essa recusa a discutir e mesmo a tentar entender a especificidade do trabalho educativo leva Lazarini a não entender a contradição que marca o sistema público de educação na sociedade contemporânea. O crítico fala de dialética, afirma não desconsiderar a existência das contradições no sistema escolar de ensino, afirma não defender uma concepção crítico-reprodutivista, mas o fato é que não consegue apreender nem compreender a contradição analisada por Saviani. A consequiência disso é que a perspectiva de Lazarini de luta revolucionária exclui, dessa forma, a luta pela apropriação do conhecimento científico, artístico e filosófico em suas formas mais desenvolvidas. Não admite a importância do domínio do saber sistematizado para a formação da consciência de classe. Afirma que Saviani identifica

(...) equivocadamente saber elaborado (conhecimento erudito e científico) a conhecimento revolucionário, ou seja, o conhecimento capaz de elevar as "massas populares" da condição de "classe em si para classe para si" (LAZARINI, 2010, p. 90).

Vejamos qual é realmente o argumento de Saviani:

(...) não se elabora uma concepção sem método; e não se atinge a coerência sem lógica. Mais do que isso, se se trata de elaborar uma concepção que seja suscetível de se tornar hegemônica, isto é, que seja capaz de superar a concepção atualmente dominante, é necessário dispor de instrumentos lógico-metodológicos cuja força seja superior àqueles que garantem a força e coerência da concepção dominante. (...) conclui-se que a passagem do senso comum à consciência filosófica é condição necessária para situar a educação numa perspectiva revolucionária. Com efeito, é esta a única maneira de convertê-la em instrumento que possibilite aos membros das camadas populares a passagem da condição de "classe em si" para a condição de "classe para si". Ora, sem a formação da consciência de classe não existe organização e sem organização não é possível a transformação revolucionária da sociedade (SAVIANI, 1982, p. 11 e 13, grifo nosso).

Se Saviani identificasse pura e simplesmente o saber elaborado ao saber revolucionário, ele não diria que é preciso elaborar uma concepção com instrumentos 
lógico-metodológicos superiores àqueles empregados pela concepção dominante. No trecho grifado da passagem acima citada, vê-se claramente que Saviani não afirma que a educação, por si só, produzirá a passagem da consciência de classe em-si à consciência de classe para-si. O que ele afirma é que a única forma da educação escolar contribuir para essa passagem é trabalhando na direção da elevação da consciência dos alunos do nível do senso comum ao da consciência filosófica. Se, entretanto, a educação escolar mantiver o aluno ao nível do senso comum, será impossível a realização na escola das "atividades educativas emancipadoras" propostas por Tonet (2007, p. 35) como também será pouco provável que crianças, adolescentes e jovens possam encontrar "alimento intelectual, moral e artístico noutros lugares" nas palavras de Mészáros (2005, p. 54).

Mas talvez as razões pelas quais Lazarini rejeite a tese da importância da socialização do conhecimento para a transformação social fiquem mais claras quando ele afirma que para Saviani "o saber elaborado (conhecimento erudito e científico) possui um caráter ontologicamente revolucionário, pois, com a emergência da sociedade burguesa, ele se tornou 'meio de produção e/ou força produtiva'." (LAZARINI, 2010, p. 87).

Em primeiro lugar, na obra de Marx e Engels está bastante claro o fato de que o desenvolvimento das forças produtivas pela sociedade capitalista é um processo revolucionário. Entre muitas outras passagens, pode-se citar, a esse respeito, a famosa passagem do Manifesto do Partido Comunista:

A burguesia não pode existir sem revolucionar constantemente os instrumentos de produção e, com isso todas as relações sociais. (...) Essa subversão contínua da produção, esse abalo constante de todo o sistema social, essa agitação permanente e essa falta de segurança distinguem a época burguesa de todas as precedentes (MARX; ENGELS, 2005, p. 43).

Em segundo lugar, também está claro na obra dos fundadores do socialismo científico que num certo ponto do desenvolvimento da sociedade capitalista, o desenvolvimento das forças produtivas entra em contradição com as relações capitalistas de produção. Marx afirma, por exemplo, nos Grundrisse que "a partir de certo momento o desenvolvimento das forças produtivas torna-se um obstáculo para o capital; portanto a relação do capital torna-se uma barreira para o desenvolvimento das forças produtivas do trabalho" (MARX, 1987, p. 282).

Em terceiro lugar, para Marx as forças produtivas, na sociedade capitalista, contém conhecimento objetivado, ou seja, no capitalismo, o conhecimento transforma-se em força produtiva. Para Marx, as máquinas são:

(...) produtos da indústria humana; material natural, transformado em órgãos da vontade humana sobre a natureza ou de sua atuação sobre a natureza. São órgãos do cérebro humano criados pela mão humana; força objetivada do conhecimento. O desenvolvimento do capital fixo releva até que ponto o conhecimento social geral converteu-se em força produtiva imediata e, portanto, até que ponto as condições do processo da própria vida social submeteram-se ao controle do intelecto coletivo e foram remodeladas de acordo com ele (MARX, 1987, p. 230).

Ou seja, para Marx o conhecimento desempenha sim um papel revolucionário na sociedade burguesa pelo fato dele ser parte constitutiva importante das forças produtivas. E o desenvolvimento das forças produtivas entra em contradição com as relações de produção. Saviani conclui que a socialização do conhecimento pela escola entra em 
contradição com as relações capitalistas de produção e, portanto, essa luta aponta em direção ao socialismo. Lutar pelo desenvolvimento das forças produtivas e por sua apropriação socializada não é se opor às relações capitalistas de produção? Ou será que Lazarini entende que devemos destruir o conhecimento da mesma forma que os operários, no início da industrialização, destruíam as máquinas por verem nelas a origem de sua exploração?

Mas Lazarini poderia objetar que a questão é outra; que o que está em jogo no capitalismo não é ter ou não conhecimento, mas sim possibilidade de ter ou não a propriedade do conhecimento objetivado nos meios produção:

(...) na sociedade capitalista, o que define o caráter social da apropriação dos meios de produção e todo o conhecimento neles contido, bem como o seu potencial produtivo (inclusive o potencial científico), não é o conhecimento científico ou técnico que se tem de parte ou do conjunto do processo produtivo, mas sim o ser ou não ser proprietário privado desses meios (LAZARINI, 2010, p. 179).

Mas seria um despropósito de nossa parte supormos que Lazarini estivesse com isso pretendendo afirmar que Saviani acreditasse que a luta pela socialização do conhecimento na escola pudesse abalar por si só o poder do capitalista em comprar máquinas e contratar pessoas que dominem conhecimento necessário ao controle do processo produtivo. Por mais distorções que Lazarini tenha feito em sua tese, recusamonos a acreditar que ele possa estar sugerindo que um pensador marxista da envergadura de Dermeval Saviani acreditasse que a transmissão de conhecimentos sistematizados na escola interferisse diretamente na capacidade de compra dos meios de produção pelo capital. O que Saviani afirma é que a socialização do conhecimento sistematizado é necessária para a organização da classe trabalhadora em sua luta revolucionária contra as relações capitalistas de produção. Isso tudo é muito claro nos seus textos, mas vemo-nos obrigados a repetir o óbvio. O próprio Saviani já havia alertado: "como é frequiente acontecer com tudo o que é óbvio, ele acaba sendo esquecido e ocultando, na sua aparente simplicidade, problemas que escapam à nossa atenção.” (SAVIANI, 2003, p. 15).

\section{Mais uma crítica à pedagogia histórico-crítica: a partir de qual pedagogia?}

Por fim, a pergunta inevitável: qual a perspectiva pedagógica a partir da qual Lazarini formula sua frustrada crítica à pedagogia histórico-crítica? Defenderia ele outra pedagogia? Em sua tese ele nada diz a esse respeito. Como já mencionamos, Lazarini compartilha das posições de Tonet e Mészáros sobre a educação escolar. No caso de Tonet, sua concepção sobre as "atividades educativas emancipadoras" nada esclarece sobre os conteúdos e as formas dessas atividades. No caso de Mészáros também não é explicitada nenhuma perspectiva pedagógica, seja para a educação escolar, seja para a educação não escolar. Em resumo, mesmo recorrendo-se a autores nos quais Lazarini se apóia, permanece a ausência de definição de uma linha pedagógica.

Ao final da tese Lazarini menciona as críticas feitas por Duarte (2000a, 2000b, 2003) ao construtivismo, concordando parcialmente com elas, mas esclarecendo, também em nota de rodapé, que isso

(...) não significa concordância com muitas das suas conclusões e muito menos com o conjunto das suas proposições educacionais alternativas ao construtivismo. A raiz dessa divergência está na filiação irrestrita apresentada por Duarte às teorizações e proposições matriciais de 
Saviani. (...) Por ora fico apenas na indicação dessa polêmica que poder ser mais bem desenvolvida em estudos futuros (LAZARINI, 2010, p. 495).

Curioso: Lazarini concorda com as críticas de Duarte às conseqüências desastrosas do construtivismo para a educação escolar brasileira, mas discorda de muitas das conclusões dessa crítica e, é claro, discorda da defesa da pedagogia histórico-crítica como alternativa ao construtivismo. Mais curioso ainda é o fato de Lazarini admitir que o avanço do construtivismo na educação brasileira significou uma derrota para a classe trabalhadora:

Mesmo não partilhando da ideia equivocada de Saviani quando este
justapõe conhecimento científico/erudito à formação revolucionária de
classe, sem dúvida, a concomitante degradação infraestrutural e teórico-
pedagógica da educação formal brasileira, ou de qualquer outro país onde
ela efetive em condições similares, constitui uma derrota para a classe
trabalhadora. Isso porque a maioria absoluta dos filhos da classe
trabalhadora brasileira frequenta a rede pública de educação básica e,
portanto, são os mais afetados cognitivamente e, por decorrência,
científica e culturalmente pela situação lastimável em que, em regra, ela
se encontra. O precário acesso aos elementos pertinentes à educação
elementar (escrita, leitura e cálculos básicos) e à cultura científica e
erudita (incluindo aí o desenvolvimento lúdico e físico) que deveriam ser
ensinados nas escolas, segundo os respectivos níveis de ensino, não pode
ser ignorado e muito menos comemorado pelos socialistas
revolucionários (LAZARINI, 2010, p. 496-497).

Depois de escrever quase 500 páginas com o objetivo de denunciar os "gravíssimos problemas de fundamentação teórica" (Idem, p. 441) existentes no pensamento do educador marxista que tem incansavelmente lutado para que a escola pública ensine aos filhos da classe trabalhadora o conhecimento sistematizado, Lazarini mostra um lampejo de compreensão da gravidade do problema. Chega mesmo a afirmar, em nota de rodapé, que

(...) para Marx, conhecimentos técnicos, científicos e erudição cultural não seriam suficientes para fazer de quem quer que fosse um revolucionário socialista, mas a miséria intelectual dos integrantes da classe trabalhadora não constituía um predicativo revolucionário para ela (LAZARINI, 2010, p. 497).

Como fica claríssimo em toda a obra de Saviani, para ele, assim como para Marx, o conhecimento sistematizado, por si só, não faz de ninguém um revolucionário socialista. Lazarini passou toda a tese tentando provar que Saviani está em desacordo com Marx para, ao final da tese, em nome de Marx, lamentar a miséria intelectual para a qual muito contribui uma escola pública pauperizada em todos os sentidos. E ainda que, chegados a esse ponto da leitura novamente tenhamos lamentado que o autor tenha desperdiçado tanto esforço laborando no erro, veio-nos alguma expectativa de que pudesse haver algum sinal de que finalmente Lazarini, depois de tanto ler Marx e Saviani, estivesse começando a entender a importância do trabalho educativo na luta pela socialização do conhecimento. Mas nossa expectativa foi em vão. Na sequência da tese, até seu final, Lazarini limita-se a dois pontos. Primeiramente retoma a proposição de Tonet, sobre as atividades educativas emancipadoras, sem esclarecer em que elas de fato consistiriam, a não ser pelo fato de mencionar que elas estariam voltadas para a crítica à sociedade capitalista e estariam 
integradas aos "movimentos políticos de cunho revolucionário" (LAZARINI, 2010, p. 500). Em seguida lista alguns itens de uma pauta de luta dos professores, que ele prefere chamar de educadores formais, por melhores condições de trabalho e por mais verbas para educação. Chega a ser irônico que Lazarini, com apoio de Lessa, tenha acusado Saviani de empirista quando este analisou a materialidade da ação educativa e ao final da tese limite sua defesa da educação a uma pauta de luta na qual estão exatamente listados item referentes a essa materialidade.

Mas qual a relevância de nosso questionamento sobre qual seria a pedagogia defendida por Lazarini e pelos autores nos quais ele se apóia? Consideramos esse questionamento relevante porque ele remete a uma pergunta: é possível uma pedagogia marxista ou a teoria de Marx conteria uma antipedagogia?

A psicanalista francesa Catherine Millot argumenta que os postulados freudianos sobre o inconsciente implicariam a incontrolabilidade e a imprevisibilidade dos processos formativos humanos. Nesse sentido o ato educativo estaria sempre sujeito aos meandros do inconsciente do aluno e do professor, jogando por terra as pretensões de efetivação da educação como um projeto pedagógico consciente. Conclui então Millot pela impossibilidade de uma pedagogia baseada na psicanálise:

A descoberta do inconsciente tem o corolário de invalidar qualquer tentativa de construir uma ciência pedagógica que permita determinar os meios a empregar para atingir determinado objetivo. O essencial do desenvolvimento psíquico do indivíduo escapa, por existir o inconsciente, a qualquer tentativa de domínio. O saber sobre o inconsciente adquirido na experiência psicanalítica não pode ser aplicado pela pedagogia porque, embora a psicanálise esclareça os mecanismos psíquicos em que se funda o processo educacional, tal esclarecimento não aumenta o domínio sobre esse processo (MILLOT, 1987, p. 156).

Alguns marxistas afirmam que, por mais que os professores pretendam fazer do ato de ensinar, de transmitir conhecimento, uma forma de luta contra o capital, esse esforço acabará sendo anulado pela insuperável tendência dominante do sistema escolar que seria a de reprodução da lógica capitalista. Novamente os esforços por fazer do ato educativo um ato intencional de humanização mostram-se frustrados. Da mesma forma que, segundo Millot, a psicanálise não pode fundamentar uma pedagogia, para alguns marxistas estaria fadada ao fracasso, de partida, qualquer tentativa de construção de uma pedagogia marxista. Não seria essa a mensagem de mais essa crítica à obra de Saviani e à pedagogia histórico-crítica?

\section{Bibliografia}

ALTHUSSER, L. (1969) Ideología y aparatos ideológicos de Estado, Freud y Lacan. [Acesso em 27/03/2011]. Disponível em: http://www.philosophia.cl/biblioteca/Althuser/ideologicosalth.pdf

DUARTE, N. (1993) A Individualidade Para-Si. Campinas: Autores Associados. (2000a) Vigotski e o "Aprender a Aprender": crítica às apropriações neoliberais e pós-modernas da teoria vigotskiana. Campinas: Autores Associados.

(2000b) Sobre o construtivismo: contribuições a uma análise crítica. Campinas: Autores Associados.

(2003) Sociedade do conhecimento ou sociedade das ilusões? Campinas: Autores Associados. 
GRAMSCI, A. (1982) Os Intelectuais e a Organização da Cultura. Rio de Janeiro, Civilização Brasileira, $4^{a}$ ed.

ILYENKOV, E. V. (1977) The concept of ideal. In: FEDOSEYEV e outros. Philosophy in the URSS - Problems of Dialectical Materialism. Moscou, Progress Publishers, p. 71-99.

LAZARINI, A. Q. (2010) A relação entre capital e educação escolar na obra de Dermeval Saviani: apontamentos críticos. [tese doutorado em educação] Universidade Federal de Santa Catarina, 528p.

LÊNIN, V. I. (1977) Sobre a educação. Volume 1. Lisboa, Seara Nova.

LEONTIEV. A. N. (1978) O desenvolvimento do psiquismo. Lisboa: Livros Horizonte.

LESSA, S. (2007) Trabalho e proletariado no capitalismo contemporâneo. São Paulo: Cortez.

LUKÁCS, G. (2003) História e consciência de classe. Estudos sobre a dialética marxista. São Paulo: Martins Fontes. . (2004) Ontologia del ser social: el trabajo. Buenos Aires: Herramienta.

MARX, K. (1974) Teorias sobre la plusvalía. Tomo 1. Buenos Aires: Cartago.

. (1987) Elementos fundamentales para la crítica de la economia política (Grundrisse) 1857-1858. Volumen 2. Mexico: Siglo Veintiuno. . (1996a) O Capital. Livro I. Tomo 1. São Paulo, Círculo do Livro. . (1996b) O Capital. Livro I. Tomo 2. São Paulo, Círculo do Livro.

MARX, K; ENGELS, F. (2005). Manifesto do Partido Comunista. São Paulo: Boitempo. MÉSZÁROS, I. (2005) A educação para além do capital. São Paulo: Boitempo.

MILLOT, C. (1987) Freud antipedagogo. Rio de Janeiro: Zahar.

SAVIANI, D. (1982) Educação: do senso comum à consciência filosófica. São Paulo: Cortes \& Autores Associados, $2^{\mathrm{a}}$ ed.

. (2003) Pedagogia Histórico-Crítica: primeiras aproximações. Campinas: Autores Associados, $8^{\mathrm{a}}$ ed.

. (2005) Educação socialista, pedagogia histórico-crítica e os desafios de uma sociedade de classes. In: LOMBARDI, J. C.; SAVIANI, D. (orgs.) (2005) Marxismo e Educação: debates contemporâneos. Campinas: Autores Associados, p. 223-274.

TONET, I. (2007) Educação contra o capital. Maceió: EDUFAL.

\footnotetext{
${ }^{1}$ Professor titular da UNESP, campus de Araraquara. Doutor em Educação pela UNICAMP. Livre-docente em psicologia da educação pela UNESP. Pós-doutorado em educação pela Universidade de Toronto. Líder do grupo de pesquisa "Estudos Marxistas em Educação". E-mail: newton.duarte@uol.com.br

${ }^{2}$ Professor da Universidade Federal do Pará. Doutor em Engenharia da Computação. Realiza pós-doutorado no Departamento de Psicologia da Educação, UNESP, campus de Araraquara. Integrante do grupo de pesquisa "Estudos Marxistas em Educação". E-mail: ferreira@ufpa.br

${ }_{3}^{3}$ Professora da Universidade Estadual do Norte do Paraná (UENP). Mestre em educação pela UFSC. Doutoranda em Educação Escolar na UNESP, campus de Araraquara. Integrante do grupo de pesquisa "Estudos Marxistas em Educação". E-mail: julia_malanchen@ @otmail.com

${ }^{4}$ Professor da Universidade Federal do Paraná. Mestre em Educação pela UFSC. Doutorando em Educação Escolar na UNESP, campus de Araraquara. Integrante do grupo de pesquisa "Estudos Marxistas em Educação". E-mail: herrmann@ufpr.br
}

Recebido em: $\quad$ 10/11/10

Aprovado em: $\quad$ 18/02/11 